\title{
Knowledge and Practice on Ecopharmacovigilance and Medicine Storage Amongst Medical and Dental Students in Lalitpur, Nepal
}

This article was published in the following Dove Press journal: Risk Management and Healthcare Policy

\section{Nisha Jha iD' \\ Pathiyil Ravi Shankar (D) ${ }^{2}$ \\ Subish Palaian (iD ${ }^{3}$ \\ 'Department of Clinical Pharmacology and Therapeutics, KIST Medical College, Lalitpur, Nepal; ${ }^{2}$ IMU Centre for Education, International Medical University, Kuala Lumpur, Malaysia; ${ }^{3}$ Department of Clinical Sciences, College of Pharmacy and Health Sciences, Ajman University, Ajman, United Arab Emirates}

Video abstract

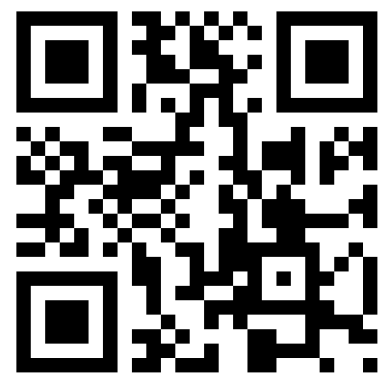

Point your SmartPhone at the code above. If you have a QR code reader the video abstract will appear. Or use: https://youtu.be/-Cep9GAA5Aw
Correspondence: Nisha Jha

Department of Clinical Pharmacology and

Therapeutics, KIST Medical College,

Lalitpur, Nepal

Tel +977-9841602808

Email nishajha32@gmail.com
Background: Medicines may remain unused and often get expired. Unused medicines can promote self-medication. Unsafe and improper medicine disposal can cause significant environmental harm. Medical and dental students as future prescribers should be aware of the safe disposal of medicines, ecopharmacovigilance and self-medication. The present study examines knowledge and practice about unused and expired medicines and medicine disposal among undergraduate medical and dental students in Nepal.

Methods: The study was conducted during September 2020 using an online survey form. First to final year undergraduate students provided their consent and signed an integrity pledge electronically. Age, gender, program of study, year of study, whether staying with family or not, method of financing education, and whether they had used any allopathic medicines during the past 6 months were noted. The total knowledge score among different subgroups was compared. The frequency of responses regarding practice items and the free-text comments were also listed. Statistical analysis was performed using Mann-Whitney test and KruskalWallis test.

Results: Altogether 441 of the 668 students (66\%) participated. The majority were below 23 years and female. Over $65 \%$ had used allopathic medicines during the last 6 months. The median knowledge score was 8 (maximum 10) and was significantly higher among older respondents, females and students in later years of study. Most kept unused medicines at home/hostel till expiry which were disposed of in the household garbage. Over $40 \%$ had educated their family members about safe medicine disposal. Knowledge scores were significantly different among subgroups according to respondents' age, gender and year of study.

Conclusion: Respondents were aware of expiry of medicines and knew methods to safely dispose expired medicines. However, they practiced self-medication, stored medications at home and did not practice the safe disposal of medications. Understanding why respondents did not dispose medicines properly is important.

Keywords: dental students, ecopharmacovigilance, medicine disposal, medical students, Nepal

A large percentage of the medicines produced are not consumed by the patients and get expired. For example, data from Germany showed approximately $10 \%$ of medicines sold in the country were disposed of in household waste. ${ }^{1}$ Unused medicines can be stored by many individuals for later use when needed, especially for minor ailments. This behavior may not always be appropriate and depends on the type of medicines, duration of use and instructions from the provider. Medicines 
stored in households can be helpful in emergencies and reduce physician visits and are thus considered as costeffective and convenient. There are many reasons for medicines not being completely used such as patient's recovery from a disease, greater number of medicines bought as compared to the need, death of the patient, fear of the medicine's adverse effects, poor patient compliance, and forgetfulness. These unused medicines are stored in homes and may ultimately lead to wastage of medicines. $^{2-4}$

There is a high probability that these unused medicines may be discarded in an inappropriate manner that can harm the environment. Long-term exposure to various types of medicines in the environment can cause toxic effects to the water system and can even affect aquatic animals, plants and microorganisms. ${ }^{5}$ This may result in the emergence of antibiotic resistance due to the availability of traces of antibiotics in the water system. ${ }^{6}$ In addition, unused medicines can become a source of accidental and intentional poisoning and can contribute to selfmedication practices. ${ }^{7}$ To address these problems leftover medicines should be properly handled to avoid hazardous effects.

Irrational prescribing may promote wastage of medicines, and future prescribers should be knowledgeable about proper medicine disposal procedures and associated harmful effects if medicines are not disposed of properly. These future health professionals are also expected to be knowledgeable about ecopharmacovigilance, defined as "the science and activities associated with the detection, evaluation, understanding and prevention of adverse effects of pharmaceuticals in the environment". ${ }^{8}$ Medical and dental students have an important role to educate and advise family members and the general public on the safe and appropriate use of medications and their appropriate disposal practices. A study from Malaysia had shown that university going health science students were storing different medicines like analgesics, antipyretics, vitamins, antibiotics, and gastrointestinal medicines. ${ }^{9}$ Students purchased medicines from community pharmacies operating near the hospitals and stored these in their rooms for future use. This process may increase the likelihood of sharing the medicines with their friends, and accidental poisoning. The issue of safe disposal of medicine is of global interest. There are specific programs in developed countries for proper medicine disposal whereas, the situation is different in developing countries like Nepal.
A study from Bangladesh has also revealed less knowledge among pharmacy students about medicine disposal techniques. About $58 \%$ of students disposed of liquid medicines via toilet or sink and which eventually reached a wastewater disposal system. ${ }^{10}$ Another study done among the medical and dental students from India has mentioned throwing medicines in domestic trash was the commonest method for disposing of the expired medicines. The study also highlighted a lack of awareness among respondents of the consequences of improper drug disposal practices and the best place for educating about these issues would be the pharmacies from where the students obtain their medicines. ${ }^{11}$ Safe and proper medicine disposal issues have to be addressed in the curriculum of the medical, dental, nursing and pharmacy graduates and also should be considered by the legislative authorities. ${ }^{11}$

A study from Nepal has shown that even pharmacists are unaware of and have inadequate knowledge regarding the safe disposal of medicines. ${ }^{12}$ Medicine takeback system is the secure system for safe and environment-friendly disposal of leftover and expired medicines wherein medicines are returned back to pharmacies or law enforcement bodies where they are destroyed without harming the environment. ${ }^{13}$ Medicine takeback systems are well established with government support in countries like Australia and Canada. Similarly, countries like the United States of America and Sweden are also having a proper system of pharmaceutical waste management. ${ }^{14,15}$

Different methods for waste disposal are recycling, incineration, chemical, physical and biological treatment processes. WHO has developed guidelines for pharmaceutical waste management that do not recommend the openair burning of healthcare waste as it can be toxic to the environment. ${ }^{16}$ A study done in Pokhara, Nepal mentioned that more than half of the participants used improper practices for medicine disposal. ${ }^{17}$

Hormones, antibiotics, lipid-lowering agents, analgesics and anti-inflammatory medicines, antihypertensives, tranquillizers, antidepressants, antiepileptics and anticancer medicines were present in water bodies in different parts of the world which impact human health as well as the environment. Improperly disposed medicines can affect human health by releasing various pollutant gases, and undegraded and toxic chemical substances. ${ }^{4,18-21}$

So far there are no studies in Nepal evaluating health professional students' knowledge and practice on medicine disposal and hence the present study was conducted to 
obtain knowledge on unused and expired medicines and medicine disposal techniques from the undergraduate medical and dental students and to explore the medicine storage process, and their practice patterns. Knowledge scores were also compared among different subgroups of respondents.

\section{Materials and Methods Study Design}

A cross-sectional survey was conducted.

\section{Ethical Approval}

The Institutional Review Committee (IRC) of KIST Medical College and Teaching Hospital, Nepal approved the study with the reference number IRC-77780509-07, dated 20th September 2020. Informed consent was obtained from the student respondents prior to enrolling them in the study. The study complied with the declaration of Helsinki for medical research among human subjects.

\section{Study Duration}

Responses were collected during 25th September to 30th September 2020.

\section{Study Population}

KIST Medical College and Teaching Hospital is an institution with medical and dental undergraduate programs. All undergraduate medical (MBBS) and undergraduate dental (BDS) students were invited to participate in the study.

\section{Sample Size}

All 686 MBBS and BDS students were contacted. The study questionnaire was administered through Google form and the link was sent to students through class representatives, social networking sites and personal emails.

Students completed the questionnaire at leisure after signing an integrity pledge and committing not to refer to any external sources or friends and neighbors while answering the survey. They also committed to only completing the survey once.

\section{Sampling Method}

All students willing to participate were included in the study.

\section{Data Collection Tool \\ Development of the Structured Questionnaire}

The questionnaire was developed after consulting the literature 12,20,21 and discussing with different content experts. The questionnaire was designed as per the research objectives and the domains for knowledge and practice regarding medicine storage and disposal. The themes and subthemes of the study were also considered.

There were two themes (knowledge and practice aspects) related to study objectives and the number of questions under each theme was decided based upon the importance of each theme in answering the research questions. The first theme was about knowledge about unused medicine storage and disposal of unused and expired medicines. The second theme dealt with the practice aspects.

\section{Questionnaire Contents}

The questionnaire had three sections. The first section collected demographic information about the study participants. The second section was about knowledge about medicine storage and disposal and the third section was regarding practice.

The demographics section had nine parameters age, gender, year of study, program of study, staying with family or in a hostel or other places, self-financing or scholarship scheme, whether having any first-degree relatives in the health field, if staying with your family does your family include a child below 2 years and whether they had used any allopathic medicines during the past 6 months. Knowledge section initially had eleven questions. The questions to assess knowledge dealt with expiry date, medicine disposal system, medicine takeback system, the hazards caused by inappropriate disposal of medicines, best method and strategy for preventing the hazardous effect of unused medicines, person responsible for improving the knowledge among households about the proper disposal of "Unused medicines", storage of medicine, appropriate way (s) of discarding expired medicines at home and the consequences for storing excess medicines at home/hostel. These were developed through a thorough review of literature and discussion among the authors. The third section had nine questions to assess the students' practice towards medicine storage and their safe disposal.

\section{Content Validity}

Content validation of the first draft of the questionnaire was performed by providing the questionnaire to three content 
experts along with the content validation template. These experts were a physician, a medical educationist and an academician from a pharmacy college. The content validation template was obtained along with the remarks of the content experts. The whole process of validation was documented. As per their responses, the order of arrangement of the questions and the terminology used were modified.

\section{Face Validity}

It was checked by administering this questionnaire to 30 alumni via email. The suggestions obtained from the alumni were considered for better readability and understanding of the statements and necessary modifications were performed.

\section{Reliability Analysis}

Cronbach's alpha was calculated from the responses of the 30 alumni and was found to be 0.65 for knowledge questions. The Cronbach value increased to 0.69 after deleting a question and this was considered adequate and no further changes were made.

\section{Scoring of the Statements}

The 10 knowledge questions were scored as ' 1 ' for correct answer and ' 0 ' for incorrect answer. For the questions from section three, the responses were not scored and were shown descriptively. The questionnaire is attached as a supplementary material file.

\section{Data Analysis}

The responses obtained were downloaded as a Microsoft Excel document and exported to IBM SPSS Statistics for Windows, Version 26 software for performing further analyses. One-sample Kolmogorov Smirnov (KS) test was used to check the normality of the data ( $p$ value less than $0.05)$. The total knowledge score was calculated by adding the scores of all the questions in section two. The maximum possible score was 10 . Inferential statistical analyses were performed using non-parametric tests as the average score was not normally distributed wherein MannWhitney $U$ test was used for dichotomous variables and Kruskal-Wallis test for variables with more than two responses. A p value less than 0.05 was considered statistically significant.

\section{Results}

A total of 441 of the 668 students $(66 \%)$ participated. Most respondents were below 23 years of age. Females were greater in number compared to males. Less than onethird of respondents had a first-degree relative in the health field and most respondents were staying with their families. Nearly $65 \%$ of respondents had used allopathic medicines during the 6 months preceding the study.

The total number of students were 668 among which 385 were females and 303 were males. Scholarship students accounted for $10 \%$ of the total (67 students). We obtained more responses from scholarship students, MBBS students and male students. However, the sample was not significantly different from the student population. The demographic characteristics is shown in Table 1.

The total knowledge score was not normally distributed on carrying out the one-sample $\mathrm{K}-\mathrm{S}$ test and hence we used median and interquartile range as measures of central tendency and variation. The median score was 8 with an interquartile range of 2 . The maximum possible score was 10 .

Table 2 shows the median knowledge scores among different categories of respondents. The knowledge was significantly higher among older respondents (greater than 23 years of age). The score was higher among females and among fourth and final year students. Surprisingly the score was higher among BDS students, but the difference was not significant.

Table 3 shows the practice of the respondents. Around $65 \%$ of respondents checked the expiry date of the medicines, and most either stored their unused medicines at home till expiry or disposed it in the household garbage. Most also followed their doctors or pharmacists' orders while taking medicines. Most respondents did not find the expiry dates to be very clear and readable on the dosage form packaging. Over $40 \%$ of respondents had educated their friends and family members about the safe disposal of medicines. This further signifies the need for the health professional students to possess enough knowledge of medicine disposal and related aspects. The median score was higher (9) among the subgroup of students who had educated their families compared to 8 among those who had not done so. The difference was, however, not statistically significant.

Table 4 shows common free-text comments made by the respondents. The importance of proper storage needs for awareness of medicine storage and disposal among the public, importance of checking expiry dates of medicines before use and of storing medicines in a cool and dry place were mentioned. Responses mentioned by at least five respondents are shown in Table 4. 
Table I Demographic Characteristics of Respondents $(n=44$ I)

\begin{tabular}{|c|c|}
\hline Characteristics & $\begin{array}{l}\text { Number } \\
\text { (Percentage) }\end{array}$ \\
\hline \multicolumn{2}{|l|}{ Age (in years) } \\
\hline $18-20$ & $209(47.4)$ \\
\hline $21-23$ & $165(37.4)$ \\
\hline $24-26$ & $48(10.9)$ \\
\hline 26 years and above & $19(4.3)$ \\
\hline \multicolumn{2}{|l|}{ Gender } \\
\hline Male & $197(44.7)$ \\
\hline Female & $244(55.3)$ \\
\hline \multicolumn{2}{|l|}{ Education } \\
\hline MBBS & $309(70.1)$ \\
\hline BDS & $132(29.9)$ \\
\hline \multicolumn{2}{|l|}{ Year of study } \\
\hline First year & $75(17)$ \\
\hline Second year & $102(23.1)$ \\
\hline Third year & 91 (20.6) \\
\hline Fourth year & $109(24.7)$ \\
\hline Final year & $64(14.5)$ \\
\hline \multicolumn{2}{|l|}{ Financing of education } \\
\hline Self-financing & $378(85.7)$ \\
\hline Scholarship & $63(14.3)$ \\
\hline \multicolumn{2}{|l|}{ Any first degree relative in medical field } \\
\hline Yes & $115(26.1)$ \\
\hline No & $326(73.9)$ \\
\hline \multicolumn{2}{|l|}{ Place of residence } \\
\hline Staying with family & $295(66.9)$ \\
\hline Staying at hostel & $87(19.7)$ \\
\hline Others & $59(13.4)$ \\
\hline \multicolumn{2}{|l|}{$\begin{array}{l}\text { If you are staying with your family does your } \\
\text { family include a child below } 2 \text { years? }\end{array}$} \\
\hline Yes & $60(13.6)$ \\
\hline No & $380(86.2)$ \\
\hline \multicolumn{2}{|l|}{$\begin{array}{l}\text { Have you used any allopathic medicines during } \\
\text { the past } 6 \text { months? }\end{array}$} \\
\hline Yes & $283(64.2)$ \\
\hline No & I58 (35.8) \\
\hline
\end{tabular}

\section{Discussion}

Medicines are synthesized in laboratories and pass through various stages such as formulation, packaging, prescribing and dispensing before reaching patients. During all stages, medicines should be handled properly, and problems with handling can cause harm to individuals and the environment. A considerable percentage of medicines are unused/expired and are expected to be either sent back to manufacturers or
Table 2 Median Knowledge Scores Among Different Subgroups of Respondents ( $n=44 \mathrm{I})$

\begin{tabular}{|c|c|c|}
\hline Characteristics & $\begin{array}{l}\text { Median } \\
\text { Score }\end{array}$ & $P$ value \\
\hline \multicolumn{3}{|l|}{ Age (in years) } \\
\hline $18-20$ & 8 & $0.017 *$ \\
\hline $21-23$ & 8 & \\
\hline $24-26$ & 9 & \\
\hline 26 years and above & 9 & \\
\hline \multicolumn{3}{|l|}{ Gender } \\
\hline Male & 8 & $<0.001$ \\
\hline Female & 9 & \\
\hline \multicolumn{3}{|l|}{ Education } \\
\hline MBBS & 8 & 0.063 \\
\hline BDS & 9 & \\
\hline \multicolumn{3}{|l|}{ Year of study } \\
\hline First year & 8 & $0.021 * *$ \\
\hline Second year & 8 & \\
\hline Third year & 8 & \\
\hline Fourth year & 9 & \\
\hline Final year & 9 & \\
\hline \multicolumn{3}{|l|}{ Place of residence } \\
\hline Staying with family & 8 & 0.850 \\
\hline Staying at hostel & 9 & \\
\hline Others & 8 & \\
\hline \multicolumn{3}{|l|}{ Any first degree relative in medical field? } \\
\hline Yes & 8 & 0.450 \\
\hline No & 9 & \\
\hline \multicolumn{3}{|l|}{$\begin{array}{l}\text { If you are staying with family does your family } \\
\text { include a child below } 2 \text { years? }\end{array}$} \\
\hline Yes & 8 & 0.361 \\
\hline No & 9 & \\
\hline \multicolumn{3}{|l|}{$\begin{array}{l}\text { Have you used any allopathic medicines } \\
\text { during the past } 6 \text { months? }\end{array}$} \\
\hline Yes & 8 & 0.522 \\
\hline No & 8 & \\
\hline
\end{tabular}

Notes: *Post hoc pairwise analysis showed statistical significance between $2 \mathrm{I}-23$ years and $23-26$ years $(p=0.022)$. **Post hoc pairwise analysis showed statistical significance between First year-Final year $(p=0.001)$; Second Year-Final year $(p=0.004)$. The bold font indicates that the results were statistically significant.

disposed of by consumers, hospitals, medicine distributors or pharmacies.

In Nepal, the concept of health insurance is at a preliminary stage and in the year 2016, the government introduced a national health insurance program which covered just $5 \%$ of the population ${ }^{22}$ and hence consumers pay out-of-pocket to purchase medicines. Being a country with poor socioeconomic status any wastage of medicines can negatively impact healthcare affordability. In addition, 
Table 3 Practice Regarding Unused and Expired Medicine Storage and Disposal $(n=44 \mathrm{I})$

\begin{tabular}{|c|c|c|}
\hline Q. No. & Statement & $\begin{array}{l}\text { Number and \% } \\
\text { of Respondents }\end{array}$ \\
\hline 1. & $\begin{array}{l}\text { How often do you check the expiry date of } \\
\text { medicines? } \\
\text { Always } \\
\text { Often } \\
\text { Sometimes } \\
\text { Rarely } \\
\text { Never }\end{array}$ & $\begin{array}{l}285(64.6) \\
97(22) \\
55(12.5) \\
3(0.7) \\
1(0.2)\end{array}$ \\
\hline 2. & $\begin{array}{l}\text { What do you do with any quantity of } \\
\text { purchased medicine remaining unused at } \\
\text { your home/hostel? } \\
\text { Throw away in household garbage } \\
\text { Flush unused medications in toilet } \\
\text { Keep at home until it gets expired } \\
\text { Burn them along with garbage } \\
\text { Return it to Pharmacy shop }\end{array}$ & $\begin{array}{l}170(38.5) \\
18(4.1) \\
197(44.7) \\
15(3.4) \\
41(9.3)\end{array}$ \\
\hline 3. & $\begin{array}{l}\text { How often do you take you medications as } \\
\text { per Doctor's/Pharmacist's advice? } \\
\text { Always } \\
\text { Often } \\
\text { Sometimes } \\
\text { Rarely } \\
\text { Never }\end{array}$ & $\begin{array}{l}202(45.8) \\
175(39.7) \\
46(10.4) \\
13(2.9) \\
5(1.2)\end{array}$ \\
\hline 4. & $\begin{array}{l}\text { When multiple medications are prescribed } \\
\text { to me/my family members, } 1 / \text { we only use } \\
\text { some of them. } \\
\text { Always } \\
\text { Often } \\
\text { Sometimes } \\
\text { Rarely } \\
\text { Never }\end{array}$ & $\begin{array}{l}28(6.3) \\
61(13.8) \\
46(10.4) \\
87(19.7) \\
219(49.8)\end{array}$ \\
\hline 5. & $\begin{array}{l}\text { How often do you practice self-medication } \\
\text { for minor illness like fever and headache? } \\
\text { Always } \\
\text { Often } \\
\text { Sometimes } \\
\text { Rarely } \\
\text { Never }\end{array}$ & $\begin{array}{l}68(15.4) \\
14 \mid(32.0) \\
155(35.1) \\
55(12.5) \\
22(5.0)\end{array}$ \\
\hline 6. & $\begin{array}{l}\text { How often you buy medicines requiring } \\
\text { a valid prescription over the counter (OTC)? } \\
\text { Always } \\
\text { Often } \\
\text { Sometimes } \\
\text { Rarely } \\
\text { Never }\end{array}$ & $\begin{array}{l}4(10.0) \\
66(15.0) \\
146(33.1) \\
106(24.0) \\
79(17.9)\end{array}$ \\
\hline 7. & $\begin{array}{l}\text { Expiry dates are very clear and readable in } \\
\text { the medicine dosage forms. } \\
\text { Yes } \\
\text { No }\end{array}$ & $\begin{array}{l}115(26.1) \\
326(73.9)\end{array}$ \\
\hline
\end{tabular}

(Continued)
Table 3 (Continued).

\begin{tabular}{|l|l|l|}
\hline Q. No. & Statement & $\begin{array}{l}\text { Number and \% } \\
\text { of Respondents }\end{array}$ \\
\hline 8. & $\begin{array}{l}\text { The following reason/s prevent or limit the } \\
\text { use of my/my family member's medications: } \\
\text { Forgetfulness }\end{array}$ & \\
& $\begin{array}{l}\text { Medication ineffectiveness } \\
\text { Medications adverse effects }\end{array}$ & $149(33.8)$ \\
& Improvement of health condition & $81(18.2)$ \\
9. & Have you ever educated your friends/family & $197(44.6)$ \\
\hline & members about safe medicine disposal? & $178(40.4)$ \\
& Yes & $263(59.6)$ \\
\hline
\end{tabular}

Nepal being a mountainous country with huge mountains and water bodies requires a more stringent medicine disposal system to prevent deleterious effects on the environment.

Of the respondents, two thirds "always" checked the expiry dates of medicines. In a study conducted in Chennai, India, among pharmacy and medical students, only $6 \%$ did not check expiry dates ${ }^{23}$ and in the same study, $60 \%$ of respondents considered the medicine to become toxic after the expiry dates. ${ }^{23}$ In another study from India among dental residents, $61 \%$ mentioned expired medicines must be returned to the manufacturer. ${ }^{24}$ Once expired, medicines can have poor efficacy leading to suboptimal therapeutic concentrations or can be even toxic. At times, certain drugs like tetracycline can even cause dangerous adverse effects like Fanconi syndrome. ${ }^{25}$

Often expiry dates of medications are not clearly displayed on the medicine packs. This can be a major issue in the case of elderly patients or patients with poor health literacy and cognitive disorders. In the present study, nearly two third of respondents mentioned the expiry dates being not clearly visible. This finding suggests that while dispensing medications the pharmacists must explain to the patients about the product expiry dates, especially the ones with near expiry dates. A proper label clearly mentioning the expiry date can also be beneficial.

Safe disposal can reduce poisoning of children with medications, protect the environment and natural resources from chemical constituents of medicines, and prevent unauthorized use. In the present study $44.7 \%$ of the 
Table 4 Common Free-Text Comments by Respondents

\begin{tabular}{|c|c|}
\hline Comment & $\begin{array}{l}\text { Number of } \\
\text { Respondents }\end{array}$ \\
\hline Medicines should be stored appropriately. & 39 \\
\hline Awareness about proper disposal practices is important and is needed for the public. & 38 \\
\hline Appreciation for a good study. & 25 \\
\hline Unused medicine should be properly checked for expiry dates before use. & 20 \\
\hline Make habit of returning unused medicines to pharmacy. & 16 \\
\hline Medicines should be bought as per need. Excess dosage forms should be avoided. & 15 \\
\hline $\begin{array}{l}\text { I have kept unused medicine safely in dry place away from sunlight and every family member check expiry date of every } \\
\text { medicine before use. }\end{array}$ & 8 \\
\hline Medicine should be stored properly. It should be kept away from sunlight and reach of children. & 8 \\
\hline Unused medicines help in emergency condition or self-medication. & 8 \\
\hline $\begin{array}{l}\text { Prescription of appropriate dose and duration of medication and public education on unused medication is very } \\
\text { important. }\end{array}$ & 7 \\
\hline $\begin{array}{l}\text { Types of medicine stored were acetaminophen, acetaminophen and ibuprofen combination, pantoprazole, atenolol, and } \\
\text { lorazepam. }\end{array}$ & 7 \\
\hline Conduct a seminar regarding this important topic for better knowledge dissemination among medical students. & 5 \\
\hline $\begin{array}{l}\text { People are buying over the counter medicines in bulk and not looking at the expiry dates and the medicines are being } \\
\text { used long term so pharmacies should limit the selling of medicines to individual basis. }\end{array}$ & 5 \\
\hline $\begin{array}{l}\text { Unused medication has resulted in medication wastage and still many families do not have knowledge on methods of } \\
\text { disposal. }\end{array}$ & 5 \\
\hline Medicines should be bought as per need. Excess dosage forms should be avoided. & 5 \\
\hline
\end{tabular}

responding students stored medicines at their home/hostel till expiry. A study from Saudi Arabia reported 37.6\% of pharmacy students and $52.5 \%$ of nursing students followed the same approach of storing the medicines till it got expired. $^{26}$ Unused medicines can also promote selfmedication among family members although our study did not correlate self-medication practices with medicine storage behavior. Studies in Nepal had reported the existence of self-medication practices among the general public $^{27}$ and students, ${ }^{28}$ and naturally, the presence of unused medications can promote self-medication practices.

Over one third of the students disposed of unused medicines in the garbage. Other studies worldwide also reported a considerable amount of medicines being disposed of in the garbage. ${ }^{3,29,30}$ It is also crucial to know the reasons for storing excess medications which can eventually help develop strategies to reduce this practice. In one review, the major reasons for unused medicines were nonadherence to the drug regimen due to various reasons, death of the patient, change in medication regimen, fear of medicine shortage, inappropriate dispensing, etc. ${ }^{31}$ In the current research the reasons for storing excess medicines were however not studied.

Only one tenth of the medicines were returned to the pharmacies. Refund for returned medicines in Nepal is not provided as approximately $80-90 \%$ of total medicines used in the country are imported from foreign countries mainly from India $^{32}$ and hence the importers and distributors discard the expired medicines under their supervision. In Nepal, the pharmacies dispense the exact number of unit doses with even medicine strips being often cut. This helps in minimizing the wastage of medicines. However, this process also limits barcoding and allows medicines to be stored without the original pack and thus compromises the stability and safety.

Based on the study findings, one can assume that the respondents were unaware of the exact procedures for 
disposing of unused and expired medications in their location. The United States Food and Drug Administration (US FDA) guidelines on medicine disposal clearly emphasize the various methods of drug disposal based on the nature of the medications. ${ }^{33}$ A study from Nepal conducted among the general public also showed improper disposal of unused and expired medications and the authors recommended a governmentfunded drug takeback system in the country. ${ }^{34}$ There has been a steady increase in online pharmacies in Nepal wherein medicines are delivered based on a scanned copy of the prescription uploaded in a smartphone application, and considering this, more stringent measures have to be put in place for managing unused and expired medications. ${ }^{35}$

Among the respondents, female students had a higher score probably signifying their willingness and curiosity to know more about medicine disposal. When compared to the medical students, dental students had high scores probably since they also deal with the management of unused dental materials in addition to medicines. The curriculum of these students does not provide education on topics related to safe medicine disposal.

While the storage of medicines was common, there were also self-medication practices noted. For instance, nearly one sixth of the respondents less commonly followed the Doctor/Pharmacists advice while taking medications. If unused medications are stored at home, this can contribute to self-medication. Nearly half the study respondents had practiced self-medication for common illnesses such as fever and headache. As mentioned earlier, self-medication by students is a common problem reported in Nepal ${ }^{27,36,37}$ and elsewhere. ${ }^{38,39}$ A probable reason for self-medication among health professional students is the easy availability of drug information sources and medicines. ${ }^{40}$ In addition, since these students consider themselves knowledgeable about medicines and health conditions they consider it appropriate to self-medicate and often even suggest over the counter (OTC) medications to neighbors, friends and family members.

Storage of medicine varies depending upon the nature of the medicine. For example, specific types of medicines like antibiotics must be taken for the full course and opioid analgesics can be used on a need basis. Regarding antibiotics, the risk of improper diversion and adverse effects is lower, but this is a high risk for opioid analgesics. We examined the storage and disposal of medicines as a general category. However, these nuances should be considered while interpreting the study findings.

The present research reported a high knowledge score among female students. It may be because female students more commonly self-medicate than males ${ }^{41}$ and hence are likely to be more knowledgeable about safe medicine disposal. There is a hospital waste management guideline in Nepal according to which the wastes are managed by landfill, burial, incineration and inertization of the pharmaceutical waste product. But there are no safe medicine disposal guidelines adopted in community pharmacies. A drug takeback system where patients can return the medicines to the pharmacies who will then send it back to the distributors has been proposed but has not been widely adopted. Knowledge about this system is low and it is not widely adopted in the country. There is the added trouble of bringing the medicines back to the pharmacy from where it was purchased and of providing the proper documentation.

Respondents checked expiry dates of medicines but sometimes the information was not easy to find. Nearly half the respondents/family stored medicines for future use. Most respondents had good knowledge about expired medicines and medicine disposal, but the practice must be improved. One-third of students disposed of medicines in the garbage and less than one-tenth of medicines were returned to pharmacies. Self-medication was also noted. The sample was broadly representative of the student population. The major area of focus is to implement a drug takeback system in the country, preferably in stages starting from the larger cities and educating the public about this system once it has been implemented. The harms of improper medicine disposal should also be mentioned.

\section{Limitations}

This study is based on a single institution and responses were obtained using an online questionnaire. So, the possibility that the students may have consulted external information sources cannot be ruled out. Moreover, the institution especially the department of pharmacology emphasizes rational use of medicines and rational prescribing and hence the findings cannot be generalized to other students in the country. No physical checking of drug storage was made, and the analyses and interpretation were purely based on student responses. Since the study is questionnaire based the Dunning-Kruger effect cannot be ignored. There may be the possibility that medicine 
storage in the homes of students may be more since they consider themselves to be future prescribers and experts in medications and hence the findings may be different from other health professional students. Authors in this research also did not identify the reasons for storing medications in the respondents' houses. Nearly half of the respondents did not indicate how they disposed of their medicine. A response rate of $65 \%$ was also a limitation of this study.

\section{Conclusion}

Medical and dental students were aware of the expiry of medicines and knew methods to safely dispose of expired medicines. However, they practiced self-medication and stored medications at home and did not provide information on how they disposed unused and expired medications. More awareness and creating a chart of disposal procedures of common medicines and popularizing the chart can be important to strengthen knowledge. The drug disposal and takeback system should be implemented in community pharmacies initially located in major cities and information about the system should be widely disseminated. Similar studies in other health professional institutions and in other regions are required.

\section{Acknowledgments}

Authors of this research would like to acknowledge all the student respondents who participated in the research and responded to the survey.

\section{Disclosure}

The authors report no conflicts of interest in this work.

\section{References}

1. Stüvel H. Kann man nach dem Verfallsdatum Medikamente nutzen? [Can medicines be used after expiry]. Gesund Magazin; 2012, Available from: http://www.onmeda.de/g-rat/verfallsdatummedikamente-318.html. Accessed January 16, 2021

2. Bound JP, Voulvoulis N. Household disposal of pharmaceuticals as a pathway for aquatic contamination in the United Kingdom. Environ Health Perspect. 2005;113(12):1705-1711. doi:10.1289/ehp.8315

3. Vogler S, Leopold C, Zuidberg C, Habl C. Medicines discarded in household garbage: analysis of a pharmaceutical waste sample in Vienna. J Pharm Policy Pract. 2014;7:6. doi:10.1186/2052-3211-7-6

4. Daughton CG. Cradle-to-cradle stewardship of drugs for minimizing their environmental disposition while promoting human health. II. Drug disposal, waste reduction, and future directions. Environ Health Perspect. 2003;111(5):775-785. doi:10.1289/ehp.5948

5. Boxall $\mathrm{AB}$. The environmental side effects of medication. EMBO Rep. 2004;5(12):1110-1116. doi:10.1038/sj.embor.7400307

6. Costanzo SD, Murby J, Bates J. Ecosystem response to antibiotics entering the aquatic environment. Mar Pollut Bull. 2005;51(14):218-223. doi:10.1016/j.marpolbul.2004.10.038
7. Beirens TM, van Beeck EF, Dekker R, Brug J, Raat H. Unsafe storage of poisons in homes with toddlers. Accid Anal Prev. 2006;38(4):772-776. doi:10.1016/j.aap.2006.02.007

8. Holm G, Snape JR, Murray-Smith R, Talbot J, Taylor D, Sörme P. Implementing ecopharmacovigilance in practice: challenges and potential opportunities. Drug Saf. 2013;36(7):533-546. doi:10.1007/ s40264-013-0049-3

9. Ali SE, Ibrahim MIM, Palaian S. Medication storage and self-medication behaviour amongst female students in Malaysia. Pharm Pract (Internet). 2010;8(4):226-232. doi:10.4321/S188636552010000400004

10. Labu Z, Al-Mamun M, Harun-or-Rashid M, Sikder K. Knowledge, awareness and disposal practice for unused medications among the students of the Private University of Bangladesh. J Biomed Pharm Res. 2013;2:26-33.

11. Sirisha A, Janardhan M, Karuna SP, Rao VY, Raikar SR, Patil S. Knowledge, attitude and practice on safe disposal of medicines among medical and dental undergraduates. J Basic Clin Res. 2016;3:5-9.

12. Paudel E, Choi E, Shrestha N. Pharmaceutical waste management in private pharmacies of Kaski District, Nepal. Int J Innov Sci Res Technol. 2019;4(8).

13. How medicine take-back works. Available from: http://www.take backyourmeds.org/why/how-medicine-take-back-works/. Accessed November 13, 2020.

14. Wu M, Atchley D, Greer L, Janssen S, Rosenberg D, Sass J. Dosed without prescription: preventing pharmaceutical contamination of our nation's drinking water. NDRC. 2009;60. Available from: https:// www.nrdc.org/sites/default/files/hea_10012001a.pdf. Accessed November 13, 2020.

15. Persson M, Sabelstrom E, Gunnarsson B. Handling of unused prescription drugs-knowledge, behaviour and attitude among Swedish people. Environ Int. 2009;35(5):771-774. doi:10.1016/j.envint.2008.10.002

16. WHO. Management of waste from injection activities at the district level: guidelines for district health managers. 2006. Available from: https://apps.who.int/iris/bitstream/handle/10665/43476/ 9241594284_eng.pdf. Accessed November 13, 2020.

17. Gyawali S, Rathore DS, Adhikari K, Shankar PR, Basnet S. Pharmacy practice and injection use in community pharmacies in Pokhara city, Western Nepal. BMC Health Serv Res. 2014;14 (1):190. doi:10.1186/1472-6963-14-190

18. Ashfaq M, Noor N, Saif Ur-Rehman M. Determination of commonly used pharmaceuticals in Hospital waste of Pakistan and evaluation of their ecological risk assessment. Clean Soil Air Water. 2017;45:1500392. doi:10.1002/clen.201500392

19. Vellinga A, Cormican S, Driscoll J, Furey M, O'Sullivan M, Cormican M. Public practice regarding disposal of unused medicines in Ireland. Sci Total Environ. 2014;478:98-102. doi:10.1016/j. scitotenv.2014.01.085

20. Helal RM, Abou HS. Self-medication in university students from the city of Mansoura, Egypt. J Environ Public Health. 2017;2017:1-7. doi:10.1155/2017/9145193

21. Angi'enda SA, Bukachi SA. Household knowledge and perceptions on disposal practices of unused medicines in Kenya. $J$ Anthropol Archaeol. 2016;4(2):1-20. doi:10.15640/jaa.v4n2a1

22. Ghimire P, Sapkota VP, Poudyal AK. Factors associated with enrolment of households in nepal's national health insurance program. Int $J$ Health Policy Manag. 2019;8(11):636-645. doi:10.15171/ijhpm.2019.54

23. Raja S, Mohapatra S, Kalaiselvi A, Rani RJ. Awareness and disposal practices of unused and expired medication among health care professionals and students in a Tertiary Care Teaching Hospital. Biomed Pharmacol J. 2018;11(4):2073. doi:10.13005/bpj/1585

24. Kulkarni SS, Sushanth VH, Prashant GM, Imranulla M, Vivek HP, da Costa FD. Current knowledge, attitude and practices of dental residents towards biomedical waste management: a cross sectional study. $J$ Global Oral Health. 2019;2(1):23-28. doi:10.25259/ JGOH_31_2019 
25. Fathallah-Shaykh S, Spitzer A. Which pharmaceuticals are known to cause Fanconi syndrome? Medscape. 2018. Available from: https:// www.medscape.com/answers/981774-114658/which-pharmaceuti cals-are-known-to-cause-fanconi-syndrome. Accessed November 14, 2020.

26. Bashatah A, Wajid S. Knowledge and disposal practice of leftover and expired medicine: a cross-sectional study from nursing and pharmacy students' perspectives. Int J Environ Res Public Health. 2020;17(6):2068. doi:10.3390/ijerph17062068

27. Paudel S, Aryal B. Exploration of self-medication practice in Pokhara valley of Nepal. BMC Public Health. 2020;20:1-5. doi:10.1186/ s12889-020-08860-w

28. Gyawali S, Shankar PR, Poudel PP, Saha A. Knowledge, attitude and practice of self-medication among basic science undergraduate medical students in a medical school in western Nepal. J Clin Diagn Res. 2015;9(12):FC17. doi:10.7860/JCDR/2015/16553.6988

29. Vogler S, de Rooij RH. Medication wasted-Contents and costs of medicines ending up in household garbage. Res Social Admin Pharm. 2018;14(12):1140-1146. doi:10.1016/j.sapharm.2018.02.002

30. Tit DM, Bungau S, Nistor Cseppento C, Copolovici DM, Buhas C. Disposal of unused medicines resulting from home treatment in Romania. J Environ Prot Ecol. 2016;17(4):1425-1433.

31. Makki M, Hassali MA, Awaisu A, Hashmi F. The prevalence of unused medications in homes. Pharmacy (Basel). 2019;7(2):61. doi:10.3390/pharmacy 7020061

32. $90 \%$ of Nepali drug market import-dependent! Available from: https:// www.nepalisansar.com/news/90-of-nepali-drug-market-importdependent/\#: :text=80\%2D90\%20percent $\% 20$ of\%20drugs,Indian $\%$ 20 and $\% 20$ third $\% 2$ Dworld\%20countries. Accessed November 13, 2020.

33. US Food and Drug Administration. Disposal of unused medicines: what you should know; 2015. Available from: http://www.fda.gov/ Drugs/ResourcesForYou/Consumers/BuyingUsingMedicineSafely/ EnsuringSafeUseofMedicine/SafeDisposalofMedicines/ucm186187. Accessed January 16, 2021
34. Sapkota B, Giri A, Bhatta B et al. Implementation of Medicine Takeback Concept at Community Level in Nepal: a Feasibility Study. 2020. Research Square. Available from: https://assets.researchs quare.com/files/rs-68526/v1/c8d598a4-6b68-4b6f-a32f2abcb7cc6b9e.pdf. Accessed on November 25, 2020.

35. Clinicone. Pharmacy with home delivery. Available from: https:// www.clinicone.com.np/clinicone-pharmacy-kathmandu/. Accessed November 13, 2020.

36. Banerjee I, Sathian B, Gupta RK, et al. Self-medication practice among preclinical university students in a medical school from the city of Pokhara, Nepal. Nepal J Epidemiol. 2016;6(2):574-581. doi:10.3126/nje.v6i2.15165

37. Khadka A, Kafle KK. Prevalence of Self-medication among MBBS students of a Medical College in Kathmandu. JNMA J Nepal Med Assoc. 2020;58(222):69-75.

38. Kumar R, Goyal A, Padhy BM, Gupta YK. Self-medication practice and factors influencing it among medical and paramedical students in India: a two-period comparative cross-sectional study. J Nat Sci Biol Med. 2016;7(2):143-148. doi:10.4103/0976-9668.184700

39. Mushtaq M, Gul S, Naz F. The practice of self-medication among Pakistani university students. Pak J Pharm Sci. 2017;30 (4):1377-1381.

40. Alam N, Saffoon N, Uddin R. Self-medication among medical and pharmacy students in Bangladesh. BMC Res Notes. 2015;8:763. doi:10.1186/s13104-015-1737-0

41. Tripković K, Milićević MŠ, Odalović M. Gender differences in predictors of self-medication with tranquillizers and sleeping pills: results of the population-based study in Serbia. Slovenian J Public Health. 2019;59(1):47-56. doi:10.2478/sjph-2020-0007
Risk Management and Healthcare Policy

\section{Publish your work in this journal}

Risk Management and Healthcare Policy is an international, peerreviewed, open access journal focusing on all aspects of public health, policy, and preventative measures to promote good health and improve morbidity and mortality in the population. The journal welcomes submitted papers covering original research, basic science, clinical \& epidemiological studies, reviews and evaluations,

\section{Dovepress}

guidelines, expert opinion and commentary, case reports and extended reports. The manuscript management system is completely online and includes a very quick and fair peer-review system, which is all easy to use. Visit http://www.dovepress.com/testimonials.php to read real quotes from published authors. 